\title{
V Domain of RAGE Interacts With AGEs on Prostate Carcinoma Cells
}

\author{
Edith Uetz von Allmen, ${ }^{1}$ Michael Koch, ${ }^{2}$ Günter Fritz, ${ }^{2 * *}$ and Daniel F. Legler ${ }^{1 *}$ \\ 'Biotechnology Institute Thurgau (BITg), University of Konstanz, Kreuzlingen, Switzerland \\ ${ }^{2}$ Department of Biology, University of Konstanz, Konstanz, Germany
}

\begin{abstract}
BACKGROUND. The expression of the scavenger receptor for advanced glycation end products (RAGE) and various ligands of RAGE correlate significantly with cancer progression. However, the mechanism of RAGE/sRAGE-induced cancer cell activation and ligand usage remain largely unknown.

METHODS. Androgen-independent, highly invasive, as well as androgen-dependent, noninvasive human prostate carcinoma $(\mathrm{CaP})$ cells were investigated for their interaction with the soluble form of RAGE (sRAGE). Using neutralizing antibodies and soluble proteins, the ligand for RAGE was identified on CaP cells and ligand binding with sRAGE was biochemically characterized.

RESULTS. Both androgen-independent, highly invasive and androgen-dependent, noninvasive CaP cells interacted with immobilized sRAGE in a surprisingly strong manner. Using C-terminal truncation variants of RAGE we identified the V domain being responsible for the adhesion of $\mathrm{CaP}$ cells to sRAGE. Moreover, we demonstrate that this adhesion cannot be blocked by $\mathrm{S100B}$ or neutralizing antibodies against $\beta$ integrins, or amphoterin. However, the CaP cell RAGE interaction was inhibited with either AGE-modified proteins, or with neutralizing antibodies against AGE or RAGE. Despite similar binding kinetics between AGE-modified BSA and different RAGE domains, only applying an excess of sRAGE, but not the VC1 or V domain of RAGE, was able to block the CaP cell RAGE interaction.

CONCLUSIONS. We identified AGEs as the ligand for RAGE on both invasive and noninvasive prostate cancer cells. Prostate (C) 2008 Wiley Liss, Inc.
\end{abstract}

\section{KEY WORDS: RAGE; advanced glycation end products; prostate carcinoma}

\section{INTRODUCTION}

The receptor for advanced glycation end products (RAGE) is a member of the immunoglobulin superfamiliy of cell surface receptors. The extracellular region of RAGE consists of one N-terminal variable (V), two constant (C1 and C2) immunoglubulinlike domains, followed by a single transmembranespanning domain and a short, highly charged intracellular C-terminal tail [1]. RAGE has multiple ligands and is implicated in development, homeostasis, inflammation, and pathogenesis of various diseases. RAGE ligands include diabetes-associated AGEs [2], Alzheimer's disease-associated amyloid fibrils [3], inflammation-associated $\beta 2$ integrin Mac-1 [4], tumor growth and metastasis-associated amphoterin/ high mobility group box 1 [5], or pro-inflammationassociated members of the S100/calgranulin family
Abbreviations: RAGE, receptor for advanced glycation end pro ducts; $\mathrm{CaP}$, prostate cancer; AGE, advanced glycation end products; FN, fibronectin.

The authors declare no competing financial interests.

Grant sponsor: Deutsche Forschungsgemeinschaft (Transregio SFB 11); Grant sponsor: Wilhelm Sander Stiftung; Grant sponsor: Thurgauische Stiftung fur Wissenschaft und Forschung; Grant sponsor: State Secretariat for Education and Research.

${ }^{*}$ Correspondence to: Daniel F. Legler, PhD, Biotechnology Institute Thurgau (BITg), University of Konstanz, Unterseestrasse 47, CH 8280 Kreuzlingen, Switzerland. E mail: daniel.legler@bitg.ch

**Correspondence to: Gunter Fritz, PhD, Department of Biology, University of Konstanz, Universtitatsstrasse 10, D 78457 Konstanz, Germany. E mail: guenter.fritz@uni konstanz.de 
[6]. Soluble, secreted isoforms of RAGE (sRAGE) consisting of the $\mathrm{V}$ and the two $\mathrm{C}$ domains have been identified that derive from an alternative splicing of the human RAGE mRNA [7,8] and are present in human serum [9,10], representing RAGE levels in tissues [11]. Interestingly however, is the fact that sRAGE can act as a decoy receptor and its administration in vitro and in vivo prevented, or reverted, RAGE signaling effects in various RAGE-associated disorders. For instance, treating apolipoprotein $\mathrm{E}$ deficient diabetic mice with sRAGE completely suppressed accelerated and advanced atherosclerosis [2], and daily administration of sRAGE to immunocompromised mice with implanted C6 glioma cells led to a dose-dependent decrease in tumor volume [5].

For several cancers, a relationship between RAGE expression and tumor progression has been noted. In prostate cancer, for instance, the expression of RAGE and S100 proteins markedly overlapped and increased toward the invasive connective tissue [12]. Kuniyasu et al. [13] described that RAGE production was enhanced in metastatic compared to non-metastatic prostate cancer, where it was co-expressed with amphoterin. Moreover, androgen deprivation provoked amphoterin production suggesting that the RAGE-amphoterin system enables a paracrine cancerstromal interaction that plays an important role in the acceleration of the metastatic potential in cancer cells of patients undergoing an androgen-deprivation therapy [13]. Most recently, Ishiguro et al. [14], provided evidence that RAGE-AGE interaction can mediate invasion and growth of hormone-refractory prostate carcinoma $(\mathrm{CaP})$ cells.

Despite the significant correlation of the expression of RAGE and various ligands of RAGE with cancer progression, the mechanism of RAGE/sRAGE-induced cancer cell activation and ligand usage remain largely unknown. In the present study we discovered that androgen-independent, highly invasive, as well as androgen-dependent, non-invasive $\mathrm{CaP}$ cells, both interacted with immobilized RAGE in a surprisingly strong manner. Moreover, we investigated which domain of RAGE induced this profound interaction and which counter-receptor on $\mathrm{CaP}$ was responsible for RAGE-CaP interactions.

\section{MATERIALS AND METHODS}

\section{Antibodies and Reagents}

Fatty acid free bovine serum albumin (BSA, catalogue number A7511), fibronectin from human plasma, collagen type IV and laminin (both from human placenta) were from Sigma (Buchs, Switzerland). A neutralizing goat polyclonal antibody specific for peptide 42-59 (within the $\mathrm{V}$ domain) of human RAGE
[15], was from Chemicon International (Temecula, CA). Phycoerythrin conjugated donkey $\mathrm{F}\left(\mathrm{ab}^{\prime}\right)_{2}$ fragment of anti-rabbit IgG was from Rockland Immunochemicals (Gilbertsville, PA). Neutralizing rabbit pAb against AGEs [such as N-E-(carboxymethyl)-lysine, one of the major components of AGEs] was obtained from Abcam (Cambridge, UK). Rabbit $\mathrm{pAb}$ raised against a synthetic peptide comprising residues 100-200 of human amphoterin was from Lifespan Biosciences (Seattle, WA). The following neutralizing mouse $\mathrm{mAb}$ generated against human $\beta$ integrin subunits were used: antiCD29 4B4 ( $\beta 1$; Beckman Coulter, Nyon, Switzerland), anti-CD18 7E4 ( $\beta 2$; Immunotech, Beckman Coulter), and anti-CD61 B3A ( $\beta 3$; Chemicon International). Control mouse IgG1 was purchased from Dako (DakoCytomation, Baar, Switzerland). GRGDS and the cyclic RGD (cRGD) peptides were from Bachem (Bubendorf, Switzerland). AGE-BSA was prepared according to Valencia et al. [16]. In brief, a solution of $50 \mathrm{mg} / \mathrm{ml} \mathrm{BSA}, 500 \mathrm{mM}$ ribose in $400 \mathrm{mM}$ sodium phosphate buffer, $\mathrm{pH} 7.4$, was sterilized by filtration through $0.2 \mu \mathrm{m}$ and incubated at $37^{\circ} \mathrm{C}$ in the dark for 2 weeks. The extent of modification was analyzed by AGE formation specific fluorescence [17]. For adhesion experiments the buffer was changed to PBS by passage over a NAP-5 column (GE Healthcare) equilibrated in the same buffer. AGE-BSA analyzed by size exclusion chromatography had an apparent molecular mass of approximately $160 \mathrm{kDa}$ indicating that AGE modifications led to the formation of a covalent multimer of BSA.

\section{Expression and Purification of Proteins}

The recombinant extracellular RAGE domains V (amino acids 23-132), VC1 (23-243), and sRAGE (23-327), were produced as described previously [18] with following modifications. The proteins were expressed in Escherichia coli BL21(DE3) Origami B with an $\mathrm{N}$-terminal $\mathrm{His}_{6}$-tag. Cells were grown in DYT medium containing $50 \mathrm{mM}$ sodium phosphate and $0.2 \%$ glucose at $37^{\circ} \mathrm{C}$ to an OD600 nm of 0.6. The temperature was adjusted to $23^{\circ} \mathrm{C}$ and expression was induced with $0.5 \mathrm{mM}$ IPTG at OD600 $\mathrm{nm}=1$. Cells were grown for further $12 \mathrm{hr}$, chilled on ice and harvested by centrifugation. Typically $10 \mathrm{~g}$ wet weight cells were resuspended in $20 \mathrm{ml}$ of $50 \mathrm{mM}$ sodium phosphate, $30 \mathrm{mM}$ imidazole, $\mathrm{pH} 7.4$, containing a cocktail of protease inhibitors (Complete, Roche) and ruptured by two passages through a French pressure cell. The cell lysate was subjected to ultracentrifugation at $100,000 \mathrm{~g}$ for $1 \mathrm{hr}$ and the supernatant was diluted 10-fold and applied to Ni-Sepharose Fast Flow column (GE-Healthcare). The proteins were eluted with a five column volumes linear gradient to $50 \mathrm{mM}$ sodium 
phosphate, $500 \mathrm{mM}$ imidazole, $\mathrm{pH}$ 7.4. Protein was concentrated by ultrafiltration and applied to Superdex 75 column $(2.6 \times 60$, GE Healthcare). For sRAGE, column was equilibrated in $20 \mathrm{mM}$ HEPES, $300 \mathrm{mM}$ $\mathrm{NaCl}, \mathrm{pH} 7.5$, for $\mathrm{V}$ and $\mathrm{VC} 1$ buffer was $10 \mathrm{mM} \mathrm{Na}$ acetate, $150 \mathrm{mM} \mathrm{NaCl}, \mathrm{pH}$ 5.2. The $\mathrm{His}_{6}$-tag free proteins were produced by thrombin (GE Healthcare) cleavage. Protein was dialyzed against $20 \mathrm{mM}$ Tris$\mathrm{HCl}, 300 \mathrm{mM} \mathrm{NaCl}, 2 \mathrm{mM} \mathrm{CaCl}_{2}, \mathrm{pH}$ 8.0, and thrombin was added ( $0.2 \mathrm{U}$ per $\mathrm{mg}$ of protein) and incubated at room temperature for 1-2 hr. Protein still containing the $\mathrm{His}_{6}$-tag was removed by a separation on a MonoS column (GE Healthcare) using $20 \mathrm{mM}$ sodium acetate, $\mathrm{pH}$ 5.0, applying a linear gradient of $1 \mathrm{M} \mathrm{NaCl}$ over 20 column volumes. S100B was expressed and purified as described [19].

\section{Kinetic Analysis of AGE-BSA Binding to RAGE Domains}

Surface plasmon resonance protein-protein interaction analysis was performed on a Biacore $\mathrm{X}$ instrument (GE Healthcare). The proteins were immobilized covalently onto CM5 Biacore sensor chips according to the manufacturer's instructions. Briefly, proteins were diluted to $10 \mu \mathrm{g} / \mathrm{ml}$ in $10 \mathrm{mM} \mathrm{NaAc}, \mathrm{pH} 4.0$, and loaded onto the sensor chips pre-activated with EDC/NHS. After injection of the proteins, the surface of the sensor chip was blocked with ethanolamine. Typically, protein corresponding to $2000 \mathrm{RU}$ was immobilized on the sensor chip. The binding experiments were performed at $298 \mathrm{~K}$ in $20 \mathrm{mM}$ Tris- $\mathrm{HCl}, 150 \mathrm{mM} \mathrm{NaCl}, 0.005 \% \mathrm{P} 20$, $\mathrm{pH}$ 7.6, containing $50 \mu \mathrm{M} \mathrm{ZnCl}$. Between each cycle of binding, the surface was regenerated for $1 \mathrm{~min}$ with $100 \mathrm{mM}$ glycine, $\mathrm{pH}$ 2.5. The sensorgrams were analyzed by the global analysis using BiaEvaluation 3.1 software (GE-Healthcare).

\section{Human Prostate Cancer (CaP) Cell Lines}

The invasive, androgen-independent $\mathrm{CaP}$ cell line PC-3 was maintained in IMDM (BioWhittaker ${ }^{\mathrm{TM}}$ ) supplemented with $10 \%$ FCS, $100 \mathrm{U} / \mathrm{ml}$ penicillin, $100 \mu \mathrm{g} / \mathrm{ml}$ streptomycin, $2 \mathrm{mM}$ UltraGlutamine 1 (BioWhittaker ${ }^{\mathrm{TM}}$ ), and $25 \mathrm{mM}$ HEPES. Androgen-dependent, non-invasive LNCaP prostate carcinoma cells were cultivated in RPMI 1640 containing ultraglutamine 1 (Lonza, Verviers, Belgium) supplemented with $10 \%$ FCS, $100 \mathrm{U} / \mathrm{ml}$ penicillin, and $100 \mu \mathrm{g} / \mathrm{ml}$ streptomycin.

\section{Flow Cytometry}

CaP cells were harvested, washed twice with PBS, resuspended in FACS buffer (PBS containing 0.5\% FBS) and incubated with primary antibodies for $20 \mathrm{~min}$ at $4^{\circ} \mathrm{C}$. Cells were washed twice, incubated with labeled secondary antibodies, washed and the fluorescence was acquired by a LSRII ${ }^{\mathrm{TM}}$ flow cytometer using the DIVA ${ }^{\mathrm{TM}}$ software (BD Biosciences, Basel, Switzerland). Data were analyzed with the CellQuest ${ }^{\mathrm{TM}}$ software (BD Biosciences).

\section{Cell Adhesion Assay}

$\mathrm{CaP}$ cells were passaged 1 day before adhesion assays [20]. Adhesion of PC-3 and LNCaP cells was performed essentially as previously described [21,22]. Briefly, flat-bottomed Nunc Maxisorp 96-well plates (VWR International, Dietikon, Switzerland) were coated overnight with $50 \mu \mathrm{l}$ of $10 \mu \mathrm{g} / \mathrm{ml}$ recombinant RAGE proteins V, VC1, or sRAGE in PBS. Control wells received $10 \mu \mathrm{g} / \mathrm{ml}$ BSA in PBS. Wells were washed with PBS and blocked with $0.5 \%$ BSA in PBS for $2 \mathrm{hr}$ at RT and unbound protein was washed off. CaP cells $\left(1 \times 10^{5}\right.$ in $100 \mu \mathrm{l}$ pre-warmed adhesion buffer; IMDM containing $0.5 \%$ BSA) were placed into wells in triplicates in the presence or absence of competitors and incubated for $30 \mathrm{~min}$ at $37^{\circ} \mathrm{C}$. Unbound cells were removed by four to six washes with pre-warmed IMDM and bound cells were fixed with $100 \mu \mathrm{l}$ methanol for $10 \mathrm{~min}$ and stained with $0.1 \%$ crystal violet in $20 \%$ methanol for $20 \mathrm{~min}$. After washing with tap water, $100 \mu \mathrm{l}$ methanol were added per well and the absorbance was measured at $570 \mathrm{~nm}$ in an ELISA plate reader (Tecan, Crailsheim, Germany).

\section{Treatment of CaP Cells With Blocking Antibodies}

For some experiments, cell adhesion was performed in the presence of blocking antibodies. CaP cells in suspension $\left(2 \times 10^{6}\right.$ cells $/ \mathrm{ml}$ adhesion buffer $)$ were pretreated at room temperature $\left(22-24^{\circ} \mathrm{C}\right)$ with $20 \mu \mathrm{g} / \mathrm{ml}$ anti-integrin $\mathrm{mAb}$ for $15 \mathrm{~min}$. The same volume of warm adhesion buffer $\left(37^{\circ} \mathrm{C}\right)$ was added to the cells immediately before adhesion assays, revealing a final $\mathrm{Ab}$ of $10 \mu \mathrm{g} / \mathrm{ml}$. For RAGE and AGE blocking, PC-3 and LNCaP cells were allowed to adhere to immobilized sRAGE in the presence of anti-RAGE or anti-AGE pAb (1:200 each). For cell surface RAGE blocking, cells in suspension $\left(1 \times 10^{6}\right.$ cells $/ \mathrm{ml}$ in adhesion buffer $)$ were pre-treated with antibodies (1:200) at room temperature for $15 \mathrm{~min}$, washed twice to remove unbound $\mathrm{Ab}$, and subjected to adhesion assays.

\section{RESULTS}

\section{Production and Characterization of Human RAGE Domains}

Prostate cancer, in particular in metastatic cancer, expresses enhanced levels of RAGE and RAGE expression was suggested to contribute to the development 
and progression of CaP [12-14]. However, the precise function of RAGE in CaP has not been identified yet. Thus, we first produced three different RAGE domains (Fig. 1A). The extracellular, soluble domain (sRAGE) includes the amino acids 23-327 of the mature protein and forms the immunglobulin domains $\mathrm{V}, \mathrm{C} 1$, and C2. VC1 lacks the C2 domain of sRAGE and includes the amino acid sequence 23-243. Finally, the $\mathrm{V}$ domain includes amino acids 23-132. The produced RAGE domains have been characterized recently [18], are all folded correctly and capable to bind the RAGE ligand S100B $[18,23]$. The proteins were $\geq 99 \%$ pure as judged by Coomassie stained SDS-PAGE (Fig. 1B).

\section{Invasive and Non-Invasive Prostate Cancer Cells Strongly Adhere to RAGE}

Next, we investigated on $\mathrm{CaP}$ cell interaction with RAGE. To this end we immobilized human sRAGE on Maxisorp ELISA plates and performed a cell adhesion assay with human $\mathrm{CaP}$ cell lines. Non-invasive LNCaP cells strongly adhered to immobilized sRAGE in a dose-dependent manner (Fig. 2A, and data not shown). Invasive PC-3 CaP cells also adhered to coated sRAGE (Fig. 2B), but much to our surprise not more efficiently than non-invasive LNCaP cells. In order to determine the RAGE domain responsible for the interaction with CaP cells, we immobilized the V, the VC1 and the VC1C2 (sRAGE) domain of RAGE. Both V and VC1-coating provoked a robust adhesion of LNCaP and PC-3 cells (Fig. 2), providing clear evidence that the $\mathrm{V}$ domain of RAGE is responsible for the interaction with $\mathrm{CaP}$ cells. More $\mathrm{CaP}$ cells adhered to the $\mathrm{V}$ and the VC1 domain of RAGE compared to sRAGE, whereas CaP cells showed no binding to immobilized BSA above background, that is, cell adhesion to uncoated wells.

\section{RAGE-CaP Interaction Is Integrin Independent}

RAGE has been identified as counterreceptor for leukocyte integrins leading to cell recruitment [4]. LNCaP and PC-3 cells express high levels of $\beta 1$, low levels of $\beta 3$, and no $\beta 2$ integrin on their surface (data not shown). To identify whether integrins are counterreceptors for RAGE on $\mathrm{CaP}$, we performed adhesion assays with LNCaP (Fig. 3) and PC-3 (Fig. 4) cells to immobilized RAGE domains in the presence of a large panel of integrin-interfering competitors. The presence of EDTA, a divalent cation chelator inhibiting integrin and selectin functions, only partially inhibited PC-3 cell adhesion (Fig. 4), but had no influence on LNCaP binding to RAGE domains (Fig. 3). All other competitors, including cyclo-RGD, a non-selective competitive antagonist for RGD-binding integrins, RGD peptides that block interaction of RGD-binding integrins with their ligands, and the soluble ECM molecules, such as fibronectin, laminin, and collagen IV, do not affect RAGE-CaP cell interaction (Figs. 3 and 4). In contrast, $\beta 1$-integrin mediated $\mathrm{CaP}$ adhesion to immobilized fibronectin was impaired by EDTA, RGD peptides, and a $\beta 1$-integrin blocking mAb (data not shown). To corroborate the finding that $\mathrm{CaP}$ binding to RAGE is integrin independent, we incubated LNCaP (Fig. 3) and PC-3 (Fig. 4) cells with neutralizing antibodies against $\beta 1$ (CD29), $\beta 2$ (CD18), and $\beta 3$ (CD61) integrins during the adhesion assay. None of the blocking Abs or a control IgG impaired the interaction between CaP cells with RAGE, providing clear evidence that this interaction is integrin-independent.

\section{SIOOB and Amphoterin Do Not Compete for Binding of CaP to RAGE}

In order to test whether the RAGE-CaP interaction is mediated by the known RAGE ligands S100B and
A

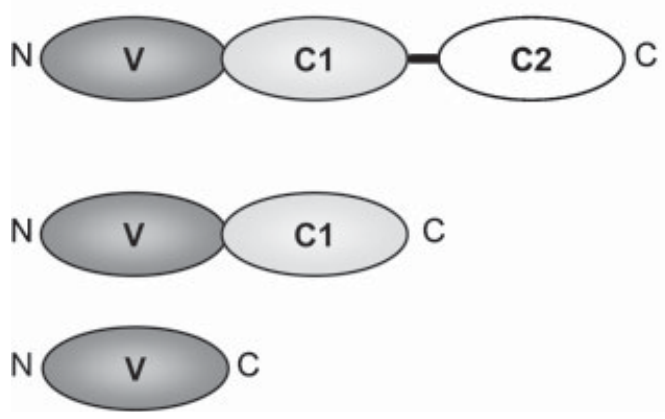

SRAGE 23-327

VC1

23-243

V

23-132
B

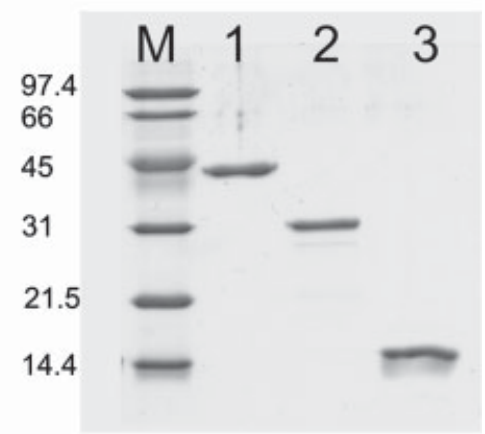

Fig. I. Schematic representation and SDS-PAGE of human RAGE domains. A: Three different proteins encompassing the Ig domains of RAGE V; Vand Cl; or V,Cl, and C2 (=sRAGE) were expressed and purified to homogeneity. B: Coomassie stained SDS-PAGE of purified RAGE domains: M, BioRad marker proteins; I, sRAGE; 2,VCl domain; 3,Vdomain. 

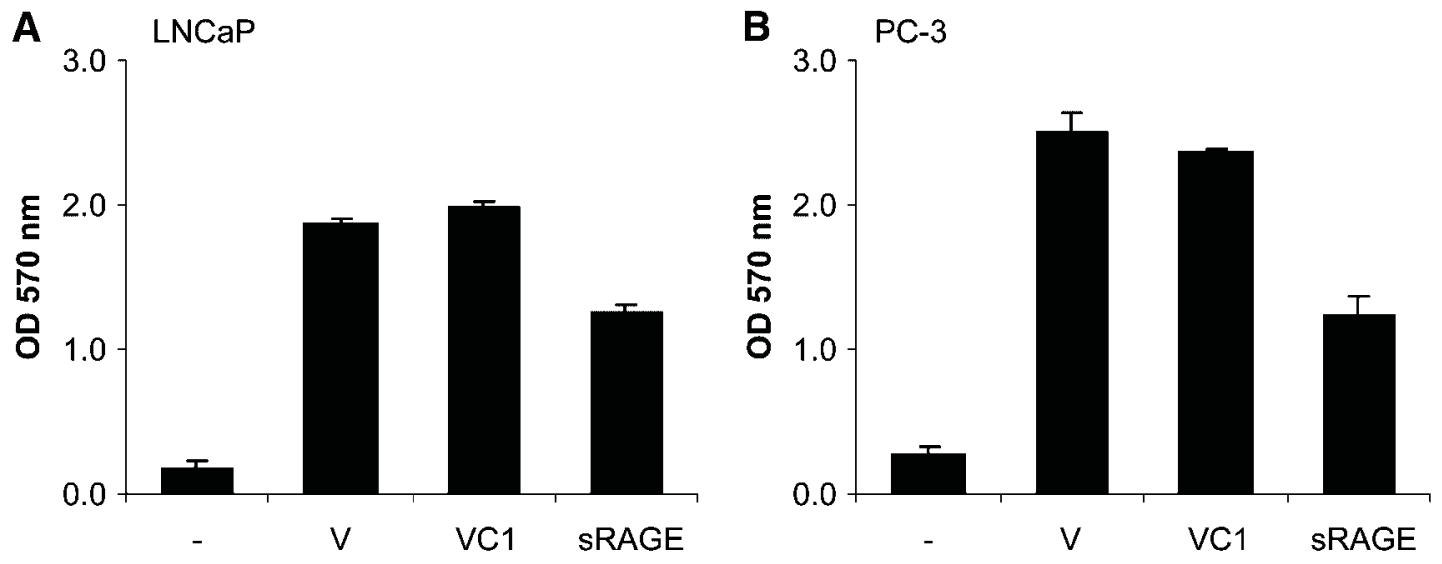

Fig. 2. Human invasive and non invasive CaP cells strongly adhere to sRAGE via the V domain. Non invasive LNCaP (A) and invasive PC 3 (B) prostate carcinoma cells specifically adhered to $10 \mu \mathrm{g} / \mathrm{ml}$ of immobilized $\mathrm{V}, \mathrm{VCl}$, or sRAGE. Adherent cells were fixed, stained with crystal violet and quantified by measuring the optical density at $570 \mathrm{~nm}$. Mean values and SD of triplicate values from one representative out of at least three independent experiments are shown.

amphoterin, we added S100B or an amphoterin blocking $\mathrm{Ab}$ to $\mathrm{CaP}$ cells during incubation with immobilized sRAGE. S100B did not or only marginally interfere with $\mathrm{LNCaP}$ or PC-3 cell interaction with RAGE (Fig. 5A,B). To investigate whether amphoterin, possibly bound to the $\mathrm{CaP}$ cell surface, contributes to cell binding to immobilized sRAGE, adhesion assays were performed in the presence or absence of a blocking polyclonal anti-amphoterin antibody. Antiamphoterin antibodies had no significant influence on RAGE-CaP interaction (Fig. 5C,D).

\section{CaP Interaction With Immobilized sRAGE Is Blocked by Soluble sRAGE and Blocking Anti-RAGE Antibodies}

As CaP cells express RAGE on their surface (as determined by flow cytometry; data not shown), we explored whether a homophilic interaction may account for the RAGE-CaP interaction. Thus, we incubated CaP cells with RAGE pAb for 15 min at RT, washed off unbound pAb and subjected the cells to an adhesion assay to immobilized sRAGE. RAGE blocking on LNCaP (Fig. 5E) and PC-3 (Fig. 5F) did not ablate the RAGE-CaP interaction, excluding a homophilic interaction. However, addition of the same anti-RAGE pAb during the adhesion assay completely abrogated $\mathrm{CaP}$ binding to immobilized sRAGE (Fig. 5E,F). Next, we investigated whether RAGE-CaP interaction can be antagonized with an excess of one of the sRAGE domains. Despite the fact that V or VC1 domains provoked a higher binding of $\mathrm{CaP}$ cells compared to sRAGE, only sRAGE was able to completely abolish the cell-protein interaction, whereas V and VC1 had no inhibitory effect at all (Fig. 5G,H).

\section{LNCaP and PC-3 Cell Binding to Immobilized sRAGE Is Significantly Reduced by Soluble AGE and Blocking Anti-AGE Antibodies}

To study a possible contribution of cell-bound AGEs to prostate epithelial cell binding to immobilized sRAGE, CaP cells were allowed to adhere in the presence or absence of an anti-AGE pAb. Low, but significant levels of AGEs were detected on both $\mathrm{CaP}$ cell lines as determined by flow cytometry (Fig. 6A,B). Neutralizing anti-AGE pAb completely abolished LNCaP (Fig. 6C) and PC-3 (Fig. 6D) binding to immobilized sRAGE. Finally, we blocked the RAGE$\mathrm{CaP}$ interaction with an excess of AGE-BSA which significantly reduced LNCaP (Fig. 6E) and PC-3 (Fig. 6F) interaction with immobilized sRAGE, whereas non-aged BSA had no significant impact on the RAGE$\mathrm{CaP}$ interaction (Fig. 6E,F).

\section{AGE-BSA Binds With nM Affınity to RAGE Domains}

In order to characterize the interaction between AGE-BSA and RAGE domain in vitro in more detail, we determined the binding kinetics by surface plasmon resonance. All three proteins-sRAGE, VC1, and $\mathrm{V}$-bound AGE-BSA with high affinity displaying $\mathrm{K}_{\mathrm{d}}$ 's ranging between 63 and $110 \mathrm{nM}$ (Fig. 7, Table I). The affinities are similar to those determined for nonglycosylated sRAGE produced recombinantly in COScells [24] or sRAGE expressed in E. coli [25]. The binding of AGE-BSA to the immobilized receptor domains was characterized by a fast association but rather slow dissociation (Table I). Interestingly, the smaller fragments $\mathrm{VC} 1$ and $\mathrm{V}$ displayed higher affinities than sRAGE toward AGE-BSA (Table I). Especially the dissociation rate of AGE-BSA from V and VC1 was 

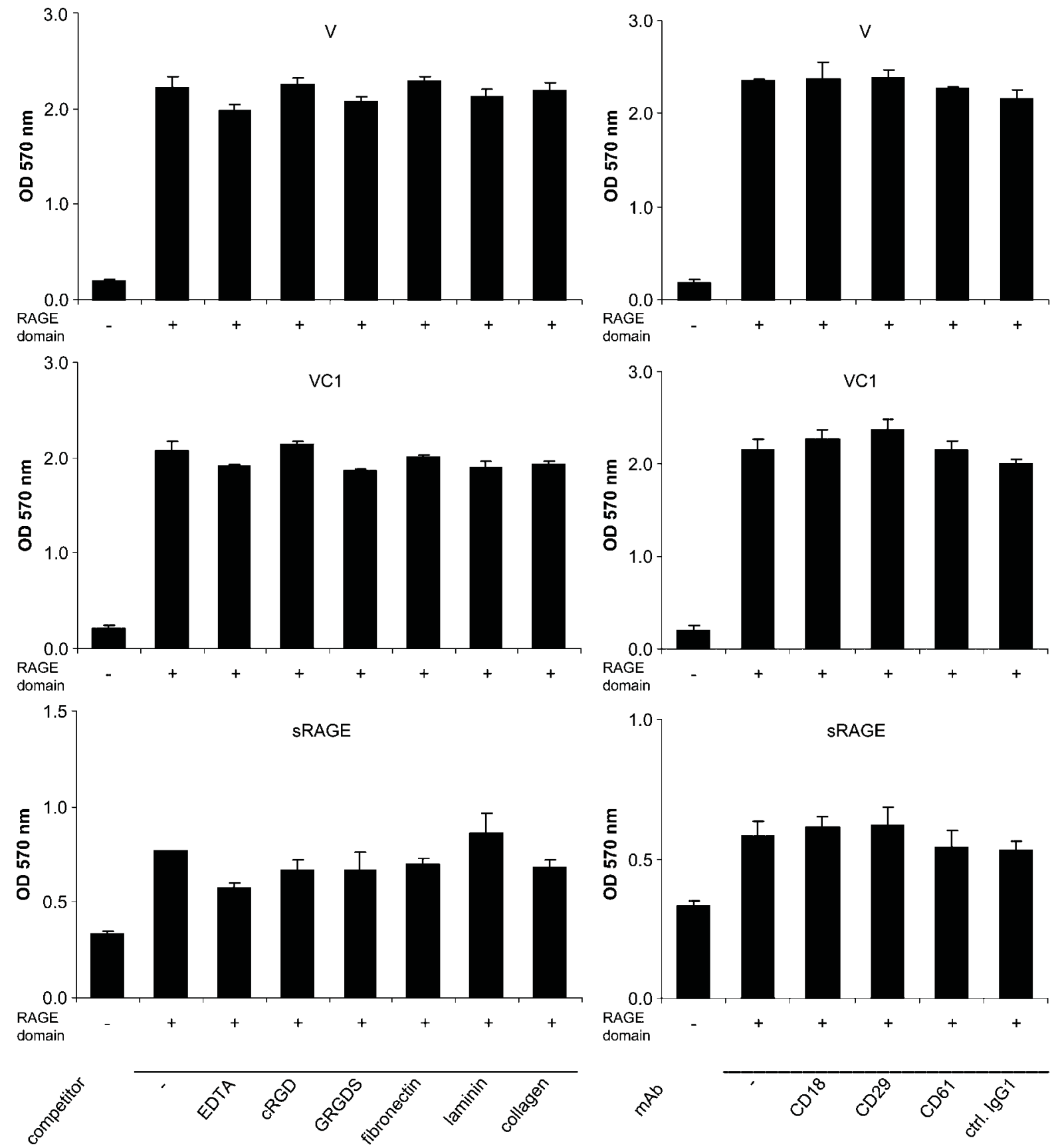

Fig. 3. Binding of LNCaP cells to sRAGE is integrin independent. LNCaP cells were allowed to interact with $10 \mu \mathrm{g} / \mathrm{ml}$ of immobilized $\mathrm{V}$ (top panel), $\mathrm{VCl}$ (middle panel), or sRAGE (bottom panel) for 30 min in the absence ( ) or presence of the competitors EDTA (I0 mM), cRGD $(10 \mu \mathrm{M})$, GRGDS (I.5 mg/ml), or the extracellular matrix proteins $(10 \mu \mathrm{g} / \mathrm{ml}$ each) fibronectin, laminin or collagen type IV (left panels). In addition, LNCaP cells were pre treated with $20 \mu \mathrm{g} / \mathrm{ml}$ of blocking $\beta I$ (CD29), $\beta 2$ (CDI8), or $\beta 3$ (CD6I) integrin antibodies, or an irrelevant (IgGI) antibody for 15 min prior to allow the cells to interact with immobilized RAGE domains (right panels). Fixed and crystal violet stained bound cells were quantified by measuring the absorbance at $570 \mathrm{~nm}$. Mean values and SD of triplicate values from one out of at least two or three independent experiments are shown.

$35 \%$ and 50\% lower than from sRAGE. Thus, AGE-BSA forms a tighter complex with the V and VC1 domains than with entire sRAGE. This is in agreement with the observation that V and VC1 mediated adhesion of PC-3 and LNCaP cells was more efficient than with entire sRAGE (Fig. 2).

\section{DISCUSSION}

Prostate cancer, which is a disease of aging, is one of the leading causes of cancer death for men. Early stage treatment of prostate cancer includes prostatectomy, radiation therapy, and androgen-deprivation. 

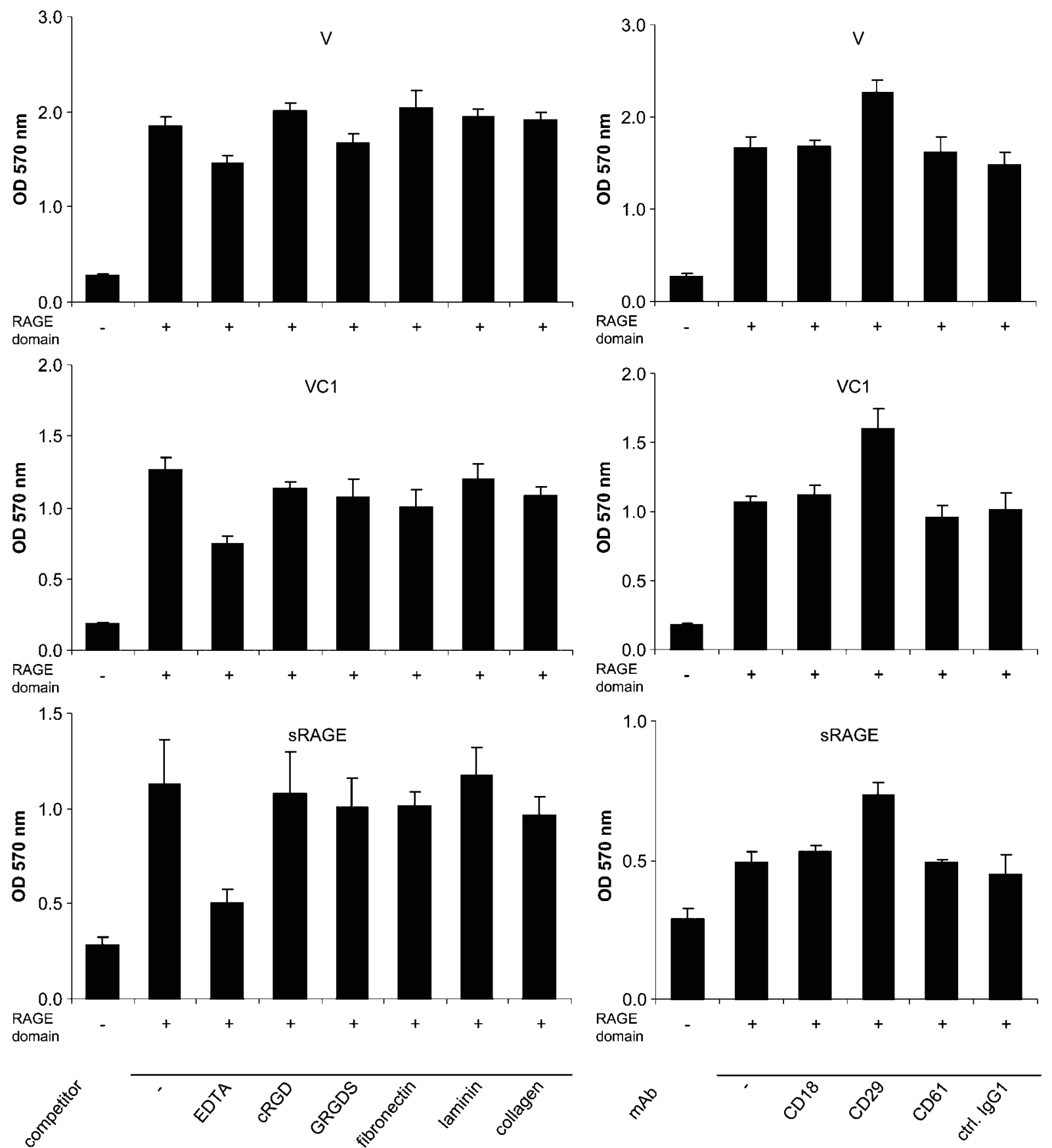

Fig. 4. Binding of PC 3 cells to $s$ RAGE is not integrin mediated.PC 3 cells were allowed to interact with $10 \mu g / \mathrm{ml} \mathrm{of} \mathrm{immobilized} \mathrm{V(top} \mathrm{panel),}$ $\mathrm{VCl}$ (middle panel), or sRAGE (bottom panel) for $30 \mathrm{~min}$ in the absence ( ) or presence of competitors and blocking mAb as in Figure 3. Cells interacting with immobilized RAGE domains were fixed, stained and quantified by measuring the optical density at $570 \mathrm{~nm}$. Mean values and SD of triplicate values from one representative out of at least two or three independent experiments are shown.

However, prostate cancer progresses at later stages are androgen-independent and acquire a high metastatic potential. Moreover, hormone-refractory prostate cancer therapy is palliative and the median survival time for such patients lies below 2 years. Unfortunately, only little is known about the mechanism underlying the development of a malignant phenotype. In this respect it is interesting to note that RAGE-S100 protein co-expression increased toward the invaded stroma of the tumor in $\mathrm{CaP}$ patients [12]. In addition, RAGE production was shown to increase significantly in metastatic compared to nonmetastatic prostate cancer and healthy prostate tissue, and was co-expressed with amphoterin [13,14]. In 

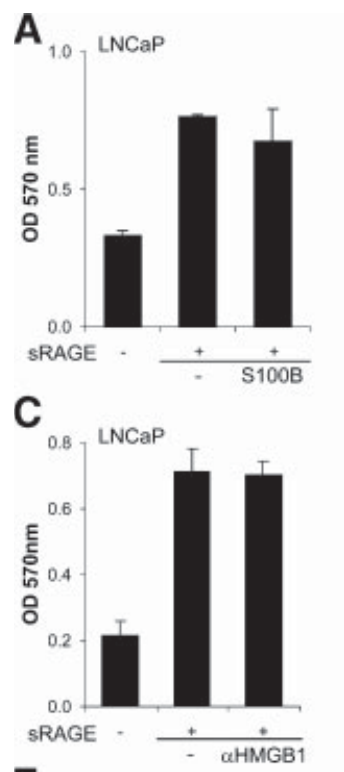

$E$
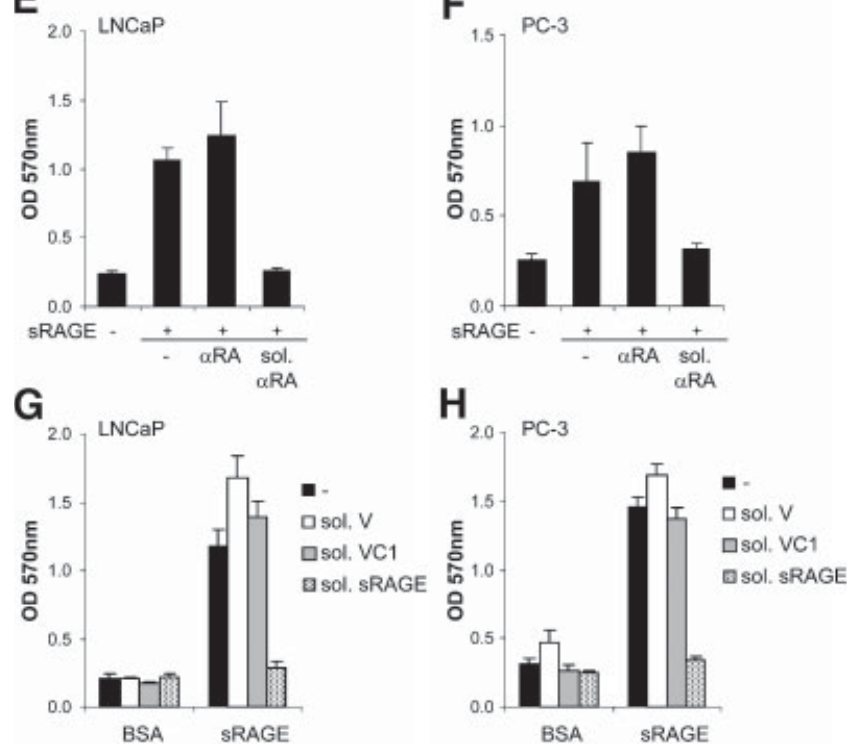

Fig. 5. The interaction of CaP cells with sRAGE can be blocked with soluble sRAGE or an anti RAGE Ab, but not with SIOOB or an anti amphoterin Ab. LNCaP (A,C,E,G) and PC 3 (B,D,F,H) cells were incubated with immobilized SRAGE in the absence () or presence of $10 \mu \mathrm{g} / \mathrm{ml}$ of soluble $\operatorname{SIOOB}(\mathrm{A}, \mathrm{B})$, a natural ligand of RAGE, $50 \mu \mathrm{g} / \mathrm{ml}$ of an amphoterin/HMGBI blocking pAb (C,D), or $80 \mu \mathrm{g} / \mathrm{ml}$ soluble RAGE domains $\mathrm{V}$ (open bars), $\mathrm{VCl}$ (gray bars), or sRAGE (dotted bars) $(G, H)$. In (E,F), CaP cells were pre incubated with an anti RAGE $A b(\alpha R A)$ for 15 min followed by washing off unbound $A b$ and allowing the cells to interact with immobilized sRAGE for $30 \mathrm{~min}$. Alternatively, cells were allowed to adhere in the presence of the anti RAGE Ab (sol $\alpha$ RA). Unbound cells were washed off and adherent cells were stained by crystal violet and quantified spectrophotometrically. Mean values and SD of triplicate values from one out of at least two or three independent experiments are shown. immunocompromized tumor models in mice, administration of sRAGE caused a dose-dependent reduction of the injected rat glioma tumor size [5]. Along this line, sRAGE transfected rat C6 glioma cells plated on amphoterin-coated matrices showed diminished proliferation and invasive properties in matrigel migration assays, whereas in full-length RAGE transfectants these activities were enhanced [5]. Several lines of evidence also suggest a role of RAGE in cell migration $[4,26,27]$. Recently, Chavakis et al. [4] demonstrated that RAGE can act as an endothelial adhesion receptor promoting leukocyte recruitment. In fact, leukocyte infiltration in a thioglycollate-induced acute peritonitis model was significantly reduced in RAGE-ablated mice, whereas in diabetic mice leukocyte recruitment into the inflamed tissue was enhanced [4]. Moreover, in vitro studies revealed that leukocyte adhesion to endothelial cells depended on RAGE- $\beta 2$-integrin interaction [4].

In the present study we demonstrate that noninvasive and invasive $\mathrm{CaP}$ cells strongly adhered to immobilized sRAGE via its $\mathrm{V}$ domain. The sRAGE-CaP cell interaction was integrin independent, as neither integrin-inhibitors nor neutralizing antiintegrin $\mathrm{mAbs}$ were able to hamper this interaction (Figs. 3 and 4). These results provide clear evidence that, in contrast to diabetic mouse models, integrins do not play a role in CaP cell adhesion to RAGE. Moreover, the interaction of RAGE with both invasive and non-invasive $\mathrm{CaP}$ cells could not be inhibited with a neutralizing anti-HMGB1/amphoterin antibody (Fig. 5). However, we were able to ablate the CaPRAGE interaction using either a neutralizing antibody against AGE-modified proteins, or with an excess of soluble AGE-BSA (Fig. 6). AGE formation includes several steps of unspecific reactions of sugars with, for example, amine groups and subsequent oxidation. Such modifications are heterogeneous and introduce additional negative charges into the molecules that mediate binding of divalent cations. Therefore, it is reasonable to assume that the divalent cation chelator EDTA may differently affect the interaction of sRAGE with LNCaP and PC-3 due to heterogeneous formation of AGEs on these two cell lines (Figs. 3 and 4). To determine the binding kinetics of the sRAGE-AGE interaction, we performed surface plasmon resonance binding measurements. The analysis of the binding curves revealed a fast association but slow dissociation (Fig. 7) showing the formation of relatively long lasting receptor-ligand complex.

Using C-terminal truncation mutants of RAGE, we demonstrate that its immunoglobulin-like $\mathrm{V}$ domain is responsible for the adhesion of CaP cells (Fig. 2). Using competitive binding studies the $\mathrm{V}$ domain was also shown to interact with carboxymethyllysine-modified 
A
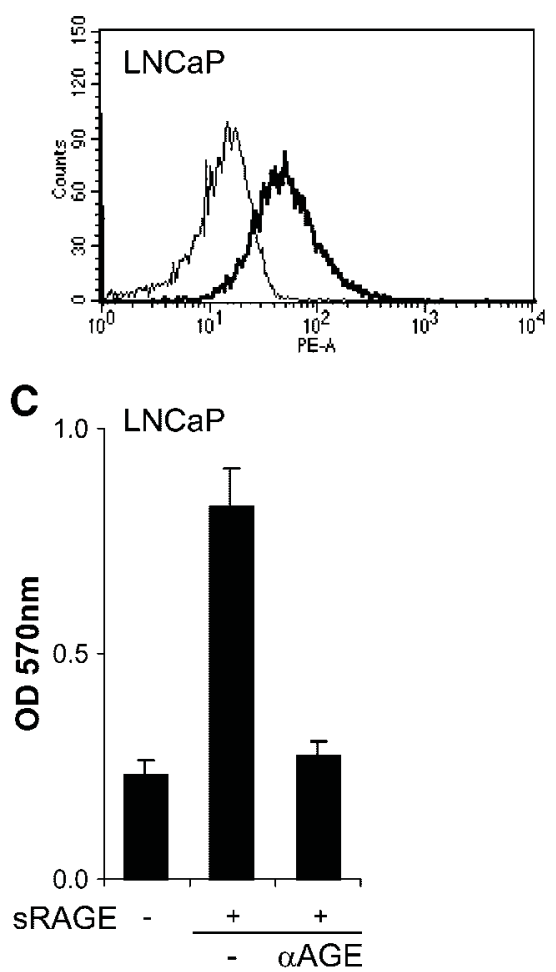

$\mathbf{E}$

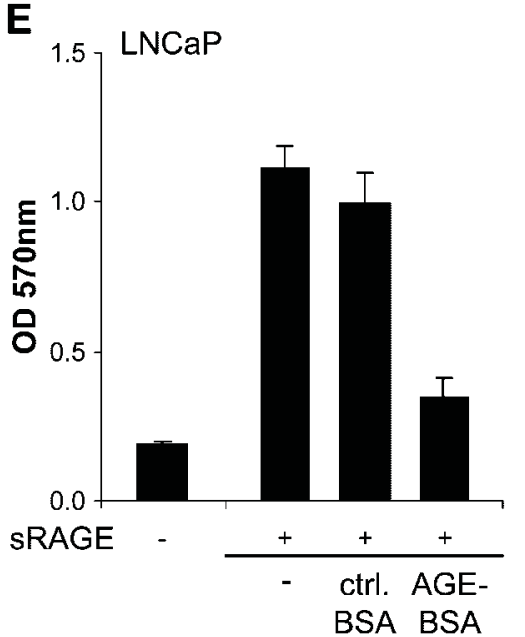

B

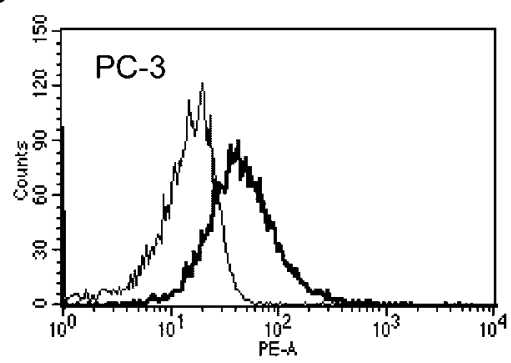

D

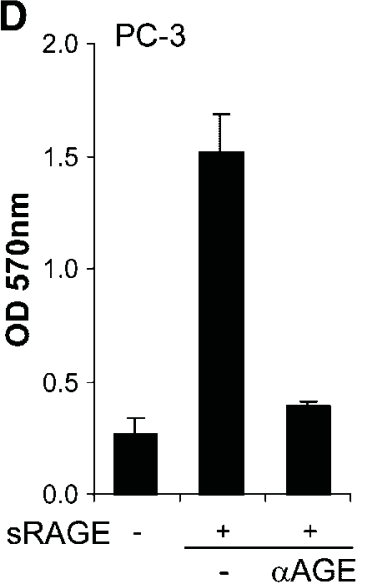

$\mathbf{F}$

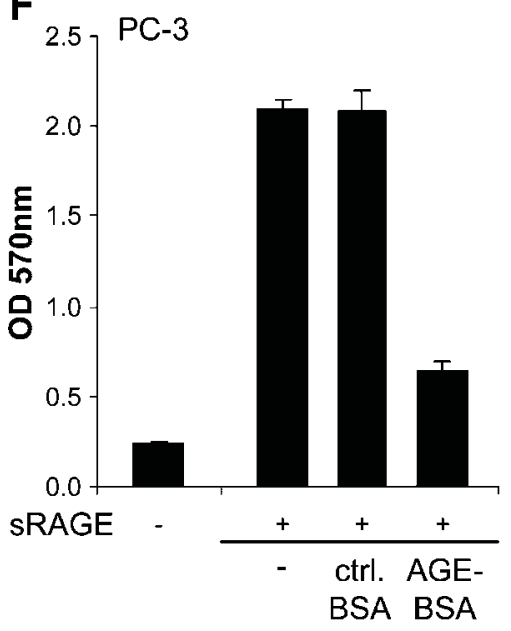

Fig. 6. AGEs on CaPcells are responsible for binding to sRAGE. AGEs on $L N C a P(\mathbf{A})$ and $P C 3(\mathbf{B})$ cells were analyzed by flow cy tometry (bold line). Control stainings using PE labeled secondary $A b$ are shown by thin lines. $L N C a P(C, E)$ and PC 3 (D,F) cells were incubated with coated sRAGE in the absence ( ) or presence of an anti AGE Ab ( $\alpha$ AGE) $(C, D), 100 \mu \mathrm{g} / \mathrm{ml}$ of AGE ribose BSA (AGE BSA) or control BSA (E,F). Cells interacting with immobilized sRAGE were fixed, stained with crystal violet, and quantified by measuring the optical density at $570 \mathrm{~nm}$. Mean values and SD of triplicate values from one representative out of at least three independent experiments are shown.

BSA [28]. Interestingly, an N-terminal truncated splice variant of RAGE, which essentially lacks the $\mathrm{V}$ domain, did not interact with glyceraldehydederived AGE-BSA in a cell free context [8]. Noteworthy, a umbilical vein endothelial cell derived cell line transfected with either wild-type or the N-truncated splice variant (lacking aa 1-101) of RAGE showed similar enhanced AGE-induced cell proliferation, whereas the $\mathrm{N}$-terminal truncated variant displayed retarded cell migration in a wound healing assay compared to wild-type RAGE [8]. Here we demonstrate that binding properties of sRAGE, VC1, and $\mathrm{V}$ toward AGE-BSA are very similar (Fig. 7). To evaluate a potential therapeutic usage of the $\mathrm{V}$ (or VC1) domain as competitor for the CaP cell interaction with RAGE, we added an excess of soluble RAGE 

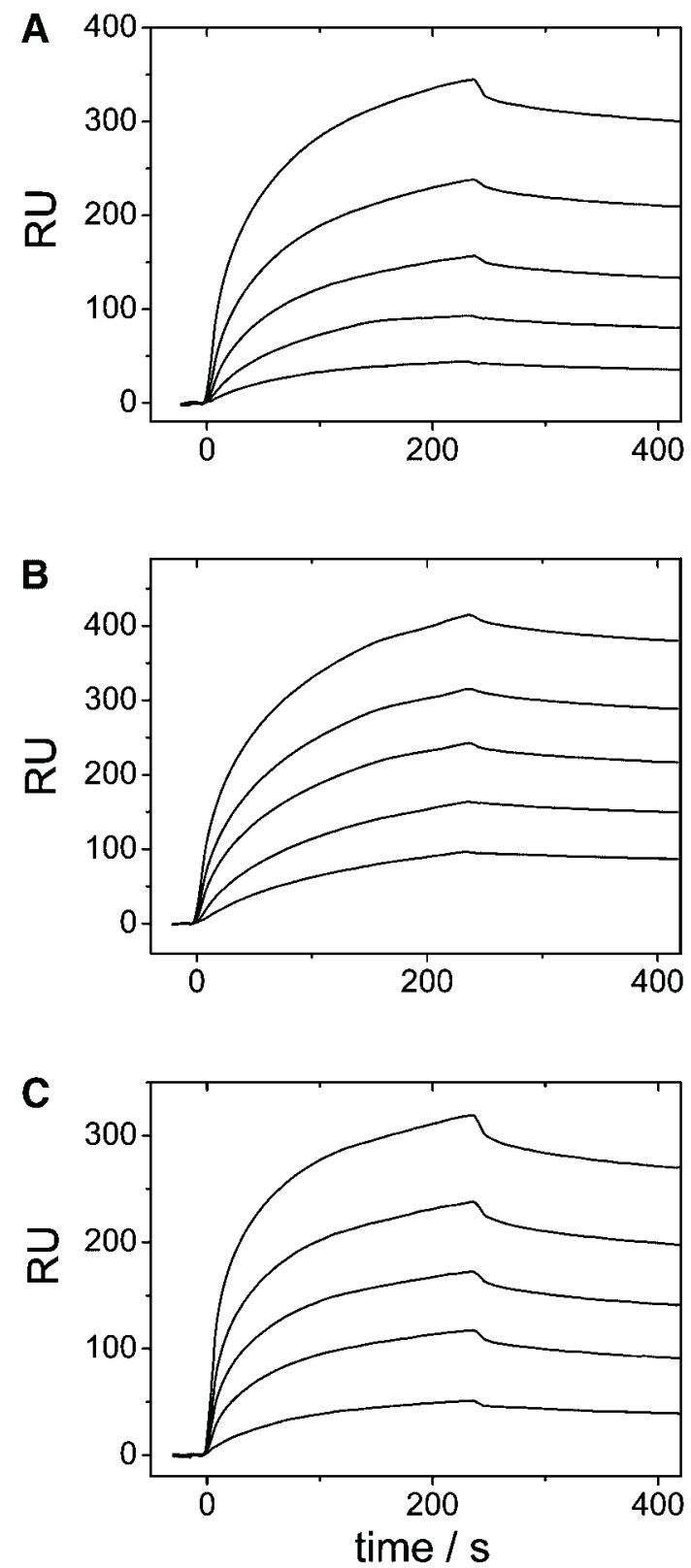

Fig. 7. Surface plasmon analysis of AGE BSA binding to RAGE domains. The binding of AGE BSA to covalently immobilized RAGE domains was analyzed by surface plasmon resonance. The binding curves of all three different proteins, sRAGE (A), VCl domain $(B)$, and $V$ domain $(\mathbf{C})$, revealed a fast association but very slow dissociation of AGE BSA. Binding curves for $0.5-2.5 \mu \mathrm{M}$ solutions of AGE BSA are shown. The kinetic parameters were very similar yielding $\mathrm{K}_{d}$ 's of $\mathrm{IOI} \pm 7 \mathrm{nM}$ for sRAGE, $72 \pm 2 \mathrm{nM}$ for $\mathrm{VCl}$, and $6 \mathrm{I} \pm 3 \mathrm{nM}$ for Vdomain, respectively.

domains to our cell adhesion assays. Despite similar $\mathrm{K}_{\mathrm{d}}$ 's, however, only sRAGE, but neither the V nor VC1 domain, was able to block $\mathrm{CaP}$ adhesion to immobilized sRAGE (Fig. 5). The differences in the ability of $\mathrm{V}$, VC1, and sRAGE to compete with immobilized sRAGE might be due to passive adsorption of sRAGE on the
TABLE I. Surface Plasmon Resonance Analysis of AGE-BSA Binding to RAGE Domains

\begin{tabular}{lccc}
\hline & $\begin{array}{c}\mathrm{k}_{\text {on }}\left(10^{3}\right. \\
\left.\mathrm{M}^{-1} \mathrm{sec}^{-1}\right)^{\mathrm{a}}\end{array}$ & $\begin{array}{c}\mathrm{k}_{\text {off }} \\
\left(10^{-4} \mathrm{sec}^{-1}\right)^{\mathrm{a}}\end{array}$ & $\mathrm{K}_{\mathrm{d}}(\mathrm{nM})^{\mathrm{a}}$ \\
\hline sRAGE & $6.3 \pm 0.7$ & $7.1 \pm 0.5$ & $110 \pm 10$ \\
VC1 & $4.9 \pm 0.6$ & $3.5 \pm 0.3$ & $71 \pm 7$ \\
V & $7.1 \pm 0.9$ & $4.5 \pm 0.7$ & $63 \pm 8$ \\
\hline
\end{tabular}

${ }^{\mathrm{a} D a t a}$ are expressed as mean $\pm \mathrm{SE}\left(\begin{array}{ll}\mathrm{n} & 4\end{array}\right)$.

synthetic surfaces of the plates as described previously for other molecules [29]. Adsorption of sRAGE or other proteins to the plates promotes close contacts of the molecules on the surface. Only sRAGE seems to effectively be able to compete with these clusters on the plate's surface whereas the single $V$ domain or tandem VC1 domains are not. These data also suggest that the V and VC1 subdomains of RAGE might be ineffective in vivo to cure $\mathrm{CaP}$.

\section{CONCLUSIONS}

Elevated RAGE expression in cancer, including CaP, has been well documented. Beside the correlation between high RAGE expression and metastasis, knowledge on the function of RAGE in prostate cancer is limited. In the present study we demonstrate that both invasive and a non-invasive $\mathrm{CaP}$ cells strongly interact with sRAGE. We provide clear evidence that the RAGE-CaP interaction is mediated by the $\mathrm{V}$ domain of RAGE. Moreover, we identified AGEs on prostate cancer cells, but not integrins, or amphoterin, as interaction partners of RAGE.

\section{ACKNOWLEDGMENTS}

We thank Martin Scheffner at University of Konstanz for generous access to the Biacore $X$ instrument. This work was supported by the Deutsche Forschungsgemeinschaft (TransregioSFB 11) and the Wilhelm SanderStiftung to GF, and the Thurgauische Stiftung für Wissenschaft und Forschung, and the State Secretariat for Education and Research to DFL. We are grateful to the Thurgauische Krebsliga for financing two tissue culture hoods. DFL is a recipient of a career development award from the Prof. Dr. Max Cloëtta Foundation.

\section{REFERENCES}

1. Neeper M, Schmidt AM, Brett J, Yan SD, Wang F, Pan YC, Elliston K, Stern D, Shaw A. Cloning and expression of a cell surface receptor for advanced glycosylation end products of proteins. J Biol Chem 1992;267(21):14998 15004.

2. Park L, Raman KG, Lee KJ, Lu Y, Ferran LJ Jr, Chow WS, Stern $\mathrm{D}$, Schmidt AM. Suppression of accelerated diabetic atheroscle rosis by the soluble receptor for advanced glycation end products. Nat Med 1998;4(9):1025 1031. 
3. Yan SD, Chen X, Fu J, Chen M, Zhu H, Roher A, Slattery T, Zhao L, Nagashima M, Morser J, Migheli A, Nawroth P, Stern D, Schmidt AM. RAGE and amyloid beta peptide neurotoxicity in Alzheimer's disease. Nature 1996;382(6593):685 691.

4. Chavakis T, Bierhaus A, Al Fakhri N, Schneider D, Witte S, Linn T, Nagashima M, Morser J, Arnold B, Preissner KT, Nawroth PP. The pattern recognition receptor (RAGE) is a counterreceptor for leukocyte integrins: A novel pathway for inflammatory cell recruitment. J Exp Med 2003;198(10):1507 1515.

5. Taguchi A, Blood DC, del Toro G, Canet A, Lee DC, Qu W, Tanji N, Lu Y, Lalla E, Fu C, Hofmann MA, Kislinger T, Ingram M, Lu A, Tanaka H, Hori O, Ogawa S, Stern DM, Schmidt AM. Blockade of RAGE amphoterin signalling suppresses tumour growth and metastases. Nature 2000;405(6784):354 360.

6. Hofmann MA, Drury S, Fu C, Qu W, Taguchi A, Lu Y, Avila C, Kambham N, Bierhaus A, Nawroth P, Neurath MF, Slattery T, Beach D, McClary J, Nagashima M, Morser J, Stern D, Schmidt AM. RAGE mediates a novel proinflammatory axis: A central cell surface receptor for S100/calgranulin polypeptides. Cell 1999;97(7):889 901.

7. Malherbe P, Richards JG, Gaillard H, Thompson A, Diener C, Schuler A, Huber G. cDNA cloning of a novel secreted isoform of the human receptor for advanced glycation end products and characterization of cells co expressing cell surface scavenger receptors and Swedish mutant amyloid precursor protein. Brain Res Mol Brain Res 1999;71(2):159 170.

8. Yonekura H, Yamamoto Y, Sakurai S, Petrova RG, Abedin MJ, Li H, Yasui K, Takeuchi M, Makita Z, Takasawa S, Okamoto H, Watanabe T, Yamamoto H. Novel splice variants of the receptor for advanced glycation end products expressed in human vascular endothelial cells and pericytes, and their putative roles in diabetes induced vascular injury. Biochem J 2003;370(Pt 3): 10971109.

9. Koyama H, Shoji T, Yokoyama H, Motoyama K, Mori K, Fukumoto S, Emoto M, Shoji T, Tamei H, Matsuki H, Sakurai $\mathrm{S}$, Yamamoto $\mathrm{Y}$, Yonekura $\mathrm{H}$, Watanabe $\mathrm{T}$, Yamamoto $\mathrm{H}$, Nishizawa Y. Plasma level of endogenous secretory RAGE is associated with components of the metabolic syndrome and atherosclerosis. Arterioscler Thromb Vasc Biol 2005;25(12): 25872593.

10. Yamagishi S, Adachi H, Nakamura K, Matsui T, Jinnouchi $Y$, Takenaka K, Takeuchi M, Enomoto M, Furuki K, Hino A, Shigeto $Y$, Imaizumi T. Positive association between serum levels of advanced glycation end products and the soluble form of receptor for advanced glycation end products in nondiabetic subjects. Metabolism 2006;55(9):1227 1231.

11. Yamagishi S, Imaizumi T. Serum levels of soluble form of receptor for advanced glycation end products (sRAGE) may reflect tissue RAGE expression in diabetes. Arterioscler Thromb Vasc Biol 2007;27(6):e32; author reply e33 e34.

12. Hermani A, Hess J, De Servi B, Medunjanin S, Grobholz R, Trojan L, Angel P, Mayer D. Calcium binding proteins S100A8 and S100A9 as novel diagnostic markers in human prostate cancer. Clin Cancer Res 2005;11(14):5146 5152.

13. Kuniyasu H, Chihara $Y$, Kondo H, Ohmori H, Ukai R. Amphoterin induction in prostatic stromal cells by androgen deprivation is associated with metastatic prostate cancer. Oncol Rep 2003;10(6):1863 1868.

14. Ishiguro H, Nakaigawa N, Miyoshi $Y$, Fujinami K, Kubota $Y$, Uemura H. Receptor for advanced glycation end products (RAGE) and its ligand, amphoterin are overexpressed and associated with prostate cancer development. Prostate 2005; 64(1):92 100 .
15. Bierhaus A, Schiekofer S, Schwaninger $M$, Andrassy M, Humpert PM, Chen J, Hong M, Luther T, Henle T, Kloting I, Morcos M, Hofmann M, Tritschler H, Weigle B, Kasper M, Smith M, Perry G, Schmidt AM, Stern DM, Haring HU, Schleicher E, Nawroth PP. Diabetes associated sustained activation of the transcription factor nuclear factor kappaB. Diabetes 2001;50(12): 27922808.

16. Valencia JV, Weldon SC, Quinn D, Kiers GH, DeGroot J, TeKoppele JM, Hughes TE. Advanced glycation end product ligands for the receptor for advanced glycation end products: Biochemical characterization and formation kinetics. Anal Biochem 2004;324(1):68 78 .

17. Westwood ME, Thornalley PJ. Molecular characteristics of methylglyoxal modified bovine and human serum albumins. Comparison with glucose derived advanced glycation end product modified serum albumins. J Protein Chem 1995;14(5): 359372.

18. Dattilo BM, Fritz G, Leclerc E, Kooi CW, Heizmann CW, Chazin WJ. The extracellular region of the receptor for advanced glycation end products is composed of two independent structural units. Biochemistry 2007;46(23):6957 6970.

19. Ostendorp T, Heizmann CW, Kroneck PM, Fritz G. Purification, crystallization and preliminary $X$ ray diffraction studies on human $\mathrm{Ca} 2+$ binding protein S100B. Acta Crystallograph Sect $\mathrm{F}$ Struct Biol Cryst Commun 2005;61(Pt 7):673 675.

20. Valster A, Tran NL, Nakada M, Berens ME, Chan AY, Symons M. Cell migration and invasion assays. Methods 2005;37(2):208 215.

21. Legler DF, Johnson Leger C, Wiedle G, Bron C, Imhof BA. The alpha $\mathrm{v}$ beta 3 integrin as a tumor homing ligand for lymphocytes. Eur J Immunol 2004;34(6):1608 1616.

22. Legler DF, Wiedle G, Ross FP, Imhof BA. Superactivation of integrin alpha $\mathrm{v}$ beta 3 by low antagonist concentrations. J Cell Sci 2001;114(Pt 8):1545 1553.

23. Ostendorp T, Leclerc E, Galichet A, Koch M, Demling N, Weigle B, Heizmann CW, Kroneck PM, Fritz G. Structural and func tional insights into RAGE activation by multimeric S100B. EMBO J 2007;26(16):3868 3878.

24. Osawa M, Yamamoto $Y$, Munesue S, Murakami N, Sakurai S, Watanabe T, Yonekura H, Uchigata Y, Iwamoto Y, Yamamoto H. De N glycosylation or G82S mutation of RAGE sensitizes its interaction with advanced glycation endproducts. Biochim Biophys Acta 2007;1770(10):1468 1474.

25. Wilton R, Yousef MA, Saxena P, Szpunar M, Stevens FJ. Expression and purification of recombinant human receptor for advanced glycation endproducts in Escherichia coli. Protein Expr Purif 2006;47(1):25 35.

26. Schmidt AM, Yan SD, Brett J, Mora R, Nowygrod R, Stern D. Regulation of human mononuclear phagocyte migration by cell surface binding proteins for advanced glycation end products. J Clin Invest 1993;91(5):2155 2168.

27. Palumbo R, Sampaolesi M, De Marchis F, Tonlorenzi R, Colombetti S, Mondino A, Cossu G, Bianchi ME. Extracellular HMGB1, a signal of tissue damage, induces mesoangioblast migration and proliferation. J Cell Biol 2004;164(3):441 449.

28. Kislinger T, Fu C, Huber B, Qu W, Taguchi A, Du Yan S, Hofmann M, Yan SF, Pischetsrieder M, Stern D, Schmidt AM. $\mathrm{N}$ (epsilon) (carboxymethyl)lysine adducts of proteins are ligands for receptor for advanced glycation end products that activate cell signaling pathways and modulate gene expression. J Biol Chem 1999;274(44):31740 31749.

29. Butler JE, Ni L, Nessler R, Joshi KS, Suter M, Rosenberg B, Chang J, Brown WR, Cantarero LA. The physical and functional behavior of capture antibodies adsorbed on polystyrene. J Immunol Methods 1992;150(1 2):77 90. 